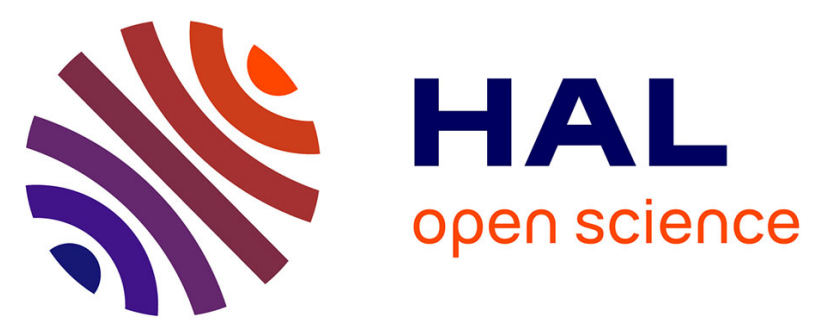

\title{
Benzylidenemalononitrile compounds as activators of cell resistance to oxidative stress and modulators of multiple signaling pathways. A structure-activity relationship study
}

Kyril Turpaev, Mikhail Ermolenko, Thierry Cresteil, Jean Claude Drapier

\section{To cite this version:}

Kyril Turpaev, Mikhail Ermolenko, Thierry Cresteil, Jean Claude Drapier. Benzylidenemalononitrile compounds as activators of cell resistance to oxidative stress and modulators of multiple signaling pathways. A structure-activity relationship study. Biochemical Pharmacology, 2011, 82 (5), pp.535. 10.1016/j.bcp.2011.05.028 . hal-00721650

\section{HAL Id: hal-00721650 \\ https://hal.science/hal-00721650}

Submitted on 29 Jul 2012

HAL is a multi-disciplinary open access archive for the deposit and dissemination of scientific research documents, whether they are published or not. The documents may come from teaching and research institutions in France or abroad, or from public or private research centers.
L'archive ouverte pluridisciplinaire HAL, est destinée au dépôt et à la diffusion de documents scientifiques de niveau recherche, publiés ou non, émanant des établissements d'enseignement et de recherche français ou étrangers, des laboratoires publics ou privés. 


\section{Accepted Manuscript}

Title: Benzylidenemalononitrile compounds as activators of cell resistance to oxidative stress and modulators of multiple signaling pathways. A structure-activity relationship study

Authors: Kyril Turpaev, Mikhail Ermolenko, Thierry Cresteil, Jean Claude Drapier

PII: S0006-2952(11)00361-3

DOI: doi:10.1016/j.bcp.2011.05.028

Reference: BCP 10920

To appear in: $\quad B C P$

Received date: $\quad$ 7-4-2011

Revised date: 24-5-2011

Accepted date: $\quad$ 25-5-2011

Please cite this article as: Turpaev K, Ermolenko M, Cresteil T, Drapier JC, Benzylidenemalononitrile compounds as activators of cell resistance to oxidative stress and modulators of multiple signaling pathways. A structure-activity relationship study, Biochemical Pharmacology (2010), doi:10.1016/j.bcp.2011.05.028

This is a PDF file of an unedited manuscript that has been accepted for publication. As a service to our customers we are providing this early version of the manuscript. The manuscript will undergo copyediting, typesetting, and review of the resulting proof before it is published in its final form. Please note that during the production process errors may be discovered which could affect the content, and all legal disclaimers that apply to the journal pertain. 


\title{
Benzylidenemalononitrile compounds as activators of cell resistance to oxidative stress and modulators of multiple signaling pathways.
}

\author{
A structure-activity relationship study.
}

\begin{abstract}
Kyril TURPAEV ${ }^{1,2,3 * \pi l}$, Mikhail ERMOLENKO ${ }^{1}$, Thierry CRESTEIL ${ }^{1}$, and Jean Claude
\end{abstract} DRAPIER $^{1 \pi}$.

${ }^{1}$ Institut de Chimie des Substances Naturelles, UPR2301 CNRS, Centre de Recherche de Gif, 91190 Gif-sur-Yvette, France

${ }^{2}$ Vavilov Institute of General Genetics, Russian Academy of Sciences, 119991 Moscow, Russia

${ }^{3}$ Center for Theoretical Problems of Physicochemical Pharmacology, Russian Academy of Sciences, 119991 Moscow, Russia

* Present address: Department of Medical Cell Biology, Uppsala University, Biomedical Center, 75123 Uppsala, Sweden. E-mail: kyril.turpaev@yahoo.com.

${ }^{\llbracket}$ Corresponding authors. Tel: + 46737425323 Fax: + 461847140 59. E-mail:

kyril.turpaev@yahoo.com; jean-claude.drapier@icsn.cnrs-gif.fr

\begin{abstract}
Abbreviations: ARE, antioxidant response element; BMN, benzylidenemalononitrile(s); ELSD, evaporative light scattering detection; ESI, electrospray ionization; GSH, glutathione; HO-1, heme oxygenase 1; IL-8, interleukin 8; LC-MS, liquid chromatography mass spectrometry; MTT, 3-(4,5-dimethylthiazol-2-yl)-2,5-diphenyltetrazolium bromide; p70S6K, p70 S6 kinase.
\end{abstract}


Abstract

Benzylidenemalononitrile (BMN) tyrphostins are well known as potent tyrosine kinase inhibitors. Moreover, in recent years it has been recognized that members of the tyrphostin family possess additional biological activities independent of their ability to inhibit protein tyrosine kinases. In this study, we examined the relationship between the structure of $49 \mathrm{BMNs}$ and related compounds, and their capacity to induce heme oxygenase 1 (HO-1) gene expression in U937 human monocytic cells, to activate upstream signaling pathways and to protect cells against menadione-induced oxidative stress. It was found that the electron-withdrawing $\left(\mathrm{NO}_{2}\right.$, $\mathrm{CN}$, halogen) groups in $\mathrm{BMN}$ molecules and double meta-MeO substituents increased the HO-1 gene induction, while the electron-donating groups in ortho/para position $(\mathrm{OH}, \mathrm{MeO}$ and $\mathrm{N}$ morpholino) significantly decreased it. The magnitude of activation of c-Jun, Nrf2, p38 MAPK, and p70S6K correlated with specific substitution patterns in the BMN structure. BMN-dependent maximal up-regulation of HO-1 required parallel increase in Nrf2 and phospho-c-Jun cellular levels. Liquid chromatography mass spectrometry (LC-MS) analysis revealed that BMNs can generate conjugates with one or two glutathione equivalent(s). This study supports the hypothesis that BMNs induce the expression of protective genes by alkylating sensitive cysteine residues of regulatory factors.

Keywords: benzylidenemalononitriles, oxidative stress, heme oxygenase, Nrf2, c-Jun. 


\section{Introduction}

Pharmacological effects of benzylidenemalononitrile (BMN) compounds have been examined since the 1990s when several of their derivatives, referred to as tyrphostins, were recognized as specific inhibitors of epidermal growth factor tyrosine kinase [1,2]. Subsequent design and testing of a series of BMNs revealed new specific inhibitors of various protein tyrosine kinases [2]. Later, it was revealed that BMN tyrphostins possess biological activities unrelated to inhibition of protein kinase activity. For instance, phenolic tyrphostins are antioxidants, free radical scavengers, and mitochondrial uncouplers [3,4]. AG-126-like tyrphostins stimulate increase in cellular glutathione (GSH) level, inhibit expression of pro-inflammatory genes as iNOS and COX-2, and suppress TNF $\alpha$ release and activation of poly (ADP-ribose) polymerase [3,5]. These tyrphostin-driven effects have been observed in experiments aimed at pharmacological suppression of septic shock, ischemia, inflammation, and injuries caused by radiation and chemotherapy [6-10]. The exact molecular mechanisms mediating the protective effects of BMN compounds remain unclear, but we have previously shown that AG-126 and several other structurally-related tyrphostins are potent activators of the expression of heme oxygenase 1 (HO-1), H-ferritin, interleukin 8 (IL-8), and several other, mainly redox-sensitive, genes. Our study also provided evidence that the gene induction capacity of BMN tyrphostins was not related to inhibition of protein tyrosine kinases. We showed that AG-126-like tyrphostins stimulate key regulators of redox-sensitive signaling systems like MAP kinases as well as AP-1 and Nrf2 transcription factors [11]. It is worth noting that BMN compounds have distant structural similarity with curcumin and chalcones. These well-known activators of protective genes have promising anti-inflammatory properties and capacities for preventing tumorigenesis and suppressing angiogenesis $[12,13]$.

The present study was focused on the structure-activity relationship of a wide series of synthetic BMN compounds and related compounds in a human monocytic cell line. BMN biological 
effects were characterized by measuring HO-1 expression, the activity of upstream signaling systems, and modulation of cell resistance to oxidative stress. Moreover, we have determined the structure of the products generated by reaction between BMNs and GSH, a key component of cellular thiol redox homeostasis.

\section{Materials and methods}

\subsection{Reagents}

Tyrphostins AG-9 (4-methoxybenzylidene)malononitrile), AG-10 (4-hydroxybenzylidenemalononitrile), and AG-126 (3-hydroxy-4-nitrobenzylidenemalononitrile) were purchased from Calbiochem (San Diego, CA). Chemicals were dissolved in DMSO. In all experiments with cell cultures, the final DMSO concentration in the medium did not exceed $0.05 \%$.

\subsection{General procedure for the synthesis of BMN compounds.}

Most of the BMN compounds were conveniently prepared in high yield by straightforward Knoevenagel condensation of the relevant aldehyde with malononitrile (1.2 equivalent) catalyzed by imidazole ( 0.01 equivalent) at room temperature in methanol. The products obtained were of at least $98 \%$ purity after re-crystallization of the product from methanol, ethanol or heptane. EMK 201 and EMK 211 were prepared from EMK 171 and EMK 181, respectively, by treatment with $\mathrm{BBr}_{3}$ (4 equivalents, $-40^{\circ} \mathrm{C}$ to room temperature). EMK 311 and $\mathrm{EMK} 321$ were prepared by condensation of 3-nitrobenzaldehyde with the corresponding methylene compounds in the presence of catalytic amounts of piperidine and acetic acid in boiling benzene [14]. EMK 381 was obtained as reported [15]. All products were of at least 98\% purity and their analytical data were in agreement with those previously reported for these compounds. All reagents were from Sigma-Aldrich (St. Louis, MO). 


\subsection{Cell treatments}

U937 cells were cultured in RPMI 1640 medium supplemented with 25 mM HEPES, pH 7.3, 5\% fetal calf serum, and gentamicin $(50 \mu \mathrm{g} / \mathrm{ml})$ (Invitrogen, Carlsbad, CA) at $37^{\circ} \mathrm{C}$ under humid $5 \%$ $\mathrm{CO}_{2}$ atmosphere. Cells were grown in $75 \mathrm{~cm}^{2}$ flasks in a volume of $15 \mathrm{ml}$ up to a density of about $0.7 \times 10^{6}$ cells $/ \mathrm{ml}$ and kept in fresh culture medium for $14 \mathrm{~h}$ before the experiments.

\subsection{RNA extraction and quantitative real-time PCR analysis.}

Cells were lysed and total RNA was extracted using the RNA extraction kit together with DNA elimination by DNase (Promega, Madison, WI), according to the manufacturer's instructions. Two $\mu \mathrm{g}$ of RNA was used to prepare cDNAs with oligo(dT) primers and AMV reverse transcriptase (Promega). Quantitative real-time PCR (RT-PCR) was performed using the Roche Light Cycler System and the FastStart DNA Master SYBR Green I kit (Roche Diagnostics, Basel, Switzerland) as previously reported [11]. Values were normalized to the relative amounts of GAPDH cDNA. All RT-PCR measurements were performed in triplicate.

\subsection{Measurement of menadione toxicity}

U937 cells were grown in 96-well microtiter plates at a density of $15 \times 10^{3} /$ well in a volume of $200 \mu$ l. The protective effect of prior 14-h incubation with $25 \mu \mathrm{M}$ BMN compounds on survival of U937 cells exposed for $5 \mathrm{~h}$ to $0-60 \mu \mathrm{M}$ menadione was quantified by colorimetric measurement of MTT reduction. Menadione (Sigma-Aldrich, St. Louis, MO) was dissolved in phosphate-buffered saline (PBS) $(\mathrm{pH} 7.3$ ) and added to culture medium to the final concentrations as indicated. A SpectraMax Plus Reader (Molecular Devices, Sunnyvale, CA) was used for quantification. Dose-effect analyses were performed according to [16]. The data were expressed using the median-effect equation $\mathrm{F}_{\mathrm{a}} / \mathrm{F}_{\mathrm{u}}=\left(\mathrm{D} / \mathrm{D}_{\mathrm{m}}\right)^{\mathrm{m}}$, where $\mathrm{D}$ is the concentration, $\mathrm{Fa}$ and $\mathrm{Fu}$ are the fractions of the cells affected and unaffected, respectively, by the concentration 
$\mathrm{D}, \mathrm{D}_{\mathrm{m}}$ is the concentration required to induce $50 \%$ cell death, and the index $m$ is a measure of the sigmoidicity of the dose-response curve [16].

\subsection{Western blotting}

U937 cells $\left(\approx 10 \times 10^{6}\right)$ were washed twice with ice-cold phosphate-buffered saline and whole cell extracts were prepared in $10 \mathrm{mM}$ Tris, $\mathrm{pH} 7.4,1 \%$ SDS, $10 \mathrm{mM} \mathrm{NaF}, 1 \mathrm{mM} \mathrm{Na}_{3} \mathrm{VO}_{4}$, and 100 $\mu \mathrm{M}$ phenylmethylsulfonyl (Sigma-Aldrich, St. Louis, MO) fluoride in a total volume of $600 \mu \mathrm{l}$ and denatured by heating at $95{ }^{\circ} \mathrm{C}$ for $5 \mathrm{~min}$. Protein concentration in each lysate was assayed colorimetrically (Bio-Rad protein reagent; Bio-Rad, Hercules, CA), and $20 \mu \mathrm{g}$ of protein was resolved by $10 \%$ SDS-PAGE. After electrophoresis, proteins were transferred to Hybond ECL nitrocellulose membranes (Amersham Biosciences, UK). Membranes were blocked in Trisbuffered saline containing 5\% nonfat milk for $2 \mathrm{~h}$. The following antibodies were used for Western analyses: rabbit anti-HO-1 (Santa Cruz Biotechnology, Santa Cruz, CA), anti-phosphop38, anti-phospho-c-Jun, anti-phospho-p70S6K (Cell Signaling Technology, Beverly, MA), and anti-Nrf2 (Abcam, Cambridge, UK) at 1:100 (anti-HO-1) or 1:1000 dilution (all other antibodies) in 1x Tris-buffered saline, $0.1 \%$ Tween 20 (TTBS), and 5\% BSA overnight. Rabbit anti- $\beta$-actin antibodies (Cell Signaling) at a 1:10000 dilution in 1×TTBS were used as a control. Appropriate horseradish peroxidase-coupled secondary goat antibodies (Dako, Glostrup, Denmark) were used for visualization using the chemiluminescent HRP substrate (Millipore, Billerica, MA) and chemiluminescence detection system (Bio-Rad, Hercules, CA). For quantification the Quantity One-4.6 software (Bio-Rad) was used.

\subsection{Absorption spectra of BMN-GSH conjugates.}

BMNs $(50 \mu \mathrm{M})$ were incubated with $\mathrm{GSH}(1 \mathrm{mM})$ in a total volume of $1 \mathrm{ml}$ of $50 \mathrm{mM}$ Tris- $\mathrm{HCl}$ buffer $(\mathrm{pH} 7.5)$ in the presence of 5\% DMSO for $1 \mathrm{~h}$ at room temperature. Spectra were recorded 
using a UV-Vis double-beam spectrophotometer (Safas UV mc2, Safas, Monaco). GSH and DMSO were present at the same concentration in the reference cuvette.

\subsection{Liquid chromatography mass spectrometry (LC-MS) analysis of BMN-GSH conjugates.}

BMN compounds ( $1 \mathrm{mM}$ ) were incubated with $5 \mathrm{mM}$ GSH (Sigma-Aldrich, St. Louis, MO) in a total volume of $400 \mu \mathrm{l}$ of $50 \mathrm{mM}$ Tris- $\mathrm{HCl}$ buffer $(\mathrm{pH} 7.5)$ in the presence of $10 \% \mathrm{MeOH}$ for $1 \mathrm{~h}$ at room temperature. The reaction mixture was analyzed using a UPLC/MS System (Waters Acquity UPLC, Waters Corporation, Milford, MA) connected to a Waters Acquity TQD triple quadripole spectrometer, with electrospray ionization (ESI) and a Waters Acquity ELSD detector. Separations were carried out on a Waters HSS C18 $(2.1 \times 50 \mathrm{~mm}, 1.8 \mu \mathrm{m})$ column at a flow rate of $0.6 \mathrm{ml} / \mathrm{min}$ using the gradient elution from $5 \%$ water-acetonitrile to $100 \%$ acetonitrile (both containing $0.1 \%$ of formic acid) over $10 \mathrm{~min}$.

\section{Results}

3.1 Time-course and dose dependence of AG-126 induced activation of HO-1 expression.

We have previously reported that the cytoprotective protein $\mathrm{HO}-1$ is highly sensitive to tyrphostin AG-126 in U937 monocytic cells [11]. Here, we further characterized this effect by performing quantitative dose-response and time-course experiments. The HO-1 mRNA content increased in U937 cells together with AG-126 concentration up to $50 \mu \mathrm{M}$, to reach a maximal accumulation of about 500-fold (Fig. 1A). The HO-1 mRNA reached its maximum after a 3-h exposure to $25 \mu \mathrm{M}$ AG-126 (Fig. 1B). The HO-1 protein level was increased up to $9 \mathrm{~h}$ after exposure to AG-126, reaching an approximately 10-fold increase over the basal level (Fig. 1C).

3.2 Capacity of BMNs to induce HO-1: structure-activity relationship. 
As a hallmark of up-regulation of cell protective systems, the capacity of a series of BMNs and structurally related compounds to affect $\mathrm{HO}-1$ at both the mRNA and protein levels were examined (see Table 1). The parent benzylidenemalononitrile EMK 191 strongly activated HO-1 mRNA induction. As compared to EMK 191, in the mono-substituted BMN series with electronwithdrawing groups $\left(\mathrm{NO}_{2}, \mathrm{CN}\right.$, halogens $)$ in ortho/metalpara position and meta-MeO substituents (-I effect) increased HO-1 mRNA induction, while the electron-donating groups with strong $+R$ effect in para-position ( $\mathrm{OH}$ and $\mathrm{N}$-morpholino) significantly decreased activity. The effect of single methoxy-group in ortho or para position was insignificant. In the series of di-substituted BMNs, the net combination of the above effects could be seen, with the exception of striking loss of activity for 3,5-dinitro-BMN EMK 281, as compared to the mono-nitro substituted EMK 491, EMK 151 and EMK 121, and compounds bearing a 4-OH group in combination with electron-withdrawing groups at the ortho-position to this group (4-OH,3-MeO, for EMK 031, 4-OH,3-F for EMK 211, 4-OH,3-NO 2 for EMK 071).

\subsection{Effect of BMNs upon signaling pathways.}

A main goal of our study was to provide insights into mechanism of activation of upstream signaling systems by BMN compounds. Therefore, we examined the effects of BMNs and related compounds on the protein content and/or the phosphorylation level of key stress signaling molecules, namely the transcription factors Nrf2 and c-Jun, p70 S6 kinase (p70S6K), an mTOR substrate and key regulator of mRNA translation and p38 MAPK. As shown in Fig. 2A, a pilot study focusing on $6 \mathrm{BMNs}$ showed that a majority of these compounds tend to activate Nrf2 expression and the phosphorylation of c-Jun and p38, and to reduce the phosphorylation of p70S6K. Then, we examined the ability of BMN compounds to promote Nrf2 accumulation and c-Jun phosphorylation using an extended set of compounds (Table 1). Quantification of Western blots showed that the parent BMN (EMK 191) and the nitro-substituted BMNs (EMK 121, EMK 151, AG-126 and EMK 281) are the most effective activator of Nrf2 expression. All other 
substitutions attenuated the magnitude of Nrf2 accumulation whatever the presence of electrondonating and electron-withdrawing groups. As regards Nrf2 accumulation, twelve parasubstituted BMN compounds proved effective in the following order: $\mathrm{NO}_{2}>\mathrm{H}>$ morpholine $>$ $\mathrm{MeS}>\mathrm{CH}_{3}>\mathrm{t}-\mathrm{Bu}>\mathrm{MeO}>\mathrm{F}>\mathrm{HO}>\mathrm{CF}_{3}>\mathrm{CN}>\mathrm{Br}$, while for $\mathrm{HO}-1$ gene activation, the order was: $\mathrm{NO}_{2}>\mathrm{CN}>\mathrm{Br}>\mathrm{CH}_{3}>\mathrm{MeS}>\mathrm{F}>\mathrm{H}>\mathrm{t}-\mathrm{Bu}>\mathrm{MeO}>>\mathrm{HO}>$ morpholine. The position and number of $\mathrm{NO}_{2}$ substitution were of minor importance. In contrast, the presence of two $\mathrm{CN}$ groups on the lateral chain was indispensable, indicating that the Michael reaction acceptor functionality is critical for the Nrf2 activation (Table 1).

Stimulation of c-Jun phosphorylation was highly dependent on the structure of BMN compounds. In U937 cells exposed to parent BMN EMK 191, the level of phospho-c-Jun increased about 3-fold. The rank order of twelve BMN compounds as regards c-Jun activation was as follows: $\mathrm{NO}_{2}>\mathrm{CF}_{3}>\mathrm{Br}>\mathrm{t}-\mathrm{Bu}>\mathrm{MeO} \geq \mathrm{F} \geq \mathrm{CN} \geq \mathrm{MeS}>\mathrm{H}>\mathrm{CH}_{3}>\mathrm{HO}>>$ morpholine. Compounds containing para- or meta- $\mathrm{NO}_{2}$ groups, 3,5-(MeO) $)_{2}(\mathrm{EMK} 131)$, 4-t-Bu (EMK 241) or halogens were effective activators of c-Jun phosphorylation (FC > 5), whereas addition of multiple MeO groups (EMK 721, EMK 731, EMK 841, EMK 851, and EMK 861) was less effective. The presence of a 4-OH group (EMK 031, EMK 071, EMK 211, and EMK 871) or a 4-morpholine group (EMK 251) led to complete reduction of c-Jun phosphorylation (Table 1).

When HO-1 mRNA accumulation elicited by BMN treatment is plotted against $\mathrm{Nrf} 2$ content (Fig. 2B) or p-c-Jun content (Fig. 2C), a significant positive correlation can be calculated. The linear correlation coefficients $\left(\mathrm{R}^{2}\right)$ were respectively $0.346(\mathrm{n}=42)$ and $0.383(\mathrm{n}=38)$ whereas Pearson correlation coefficients $\left(\rho_{\mathrm{X}, \mathrm{Y}}\right)$ were respectively 0.588 and 0.619 . Of interest, BMN compounds (EMK 031, EMK 071, EMK 211, EMK 251, EMK 861, and EMK 871) that upregulated Nrf2 accumulation but did not stimulate c-Jun phosphorylation were weak HO-1 inducers. Conversely, compounds which actively stimulated both c-Jun phosphorylation and Nrf2 accumulation (e.g. BMNs containing a $\mathrm{NO}_{2}$ group) are very potent activators of $\mathrm{HO}-1$ gene 
expression. Altogether, these data suggest that parallel actions of Nrf2 and p-c-Jun is a prerequisite for full-scale HO-1 induction, and subsequently for accumulation of HO-1 protein.

Activation of p38 phosphorylation was markedly stimulated by compounds bearing $\mathrm{NO}_{2^{-}}$and halogen benzene ring substituents (Supplemental Table 1). Regarding p-p70S6K, its level was strongly reduced $(\mathrm{FC}=0.16)$ in cells exposed to EMK 281 whereas $\mathrm{FC}$ was between 0.4 and 0.5 for EMK 311, EMK 431, EMK 211, EMK 491, EMK 621, and EMK 151 (see Fig. 2A and Supplemental Table 1). However, only slight to moderate correlation was noted between accumulation of HO-1 mRNA and either p-p38 or p-p70SK content in U937 cells treated with BMNs (data not shown).

\subsection{Protective effects of BMN compounds upon oxidative stress}

To generate oxidative stress, we exposed U937 cells to menadione, which induces cell death through superoxide generation and depletion of intracellular SH-containing molecules. Twelve compounds with different capacity to induce HO-1 were selected. In control experiments, survival of U937 cells decreased as menadione concentration increased, and at concentration over $40 \mu \mathrm{M}$ almost no cell survived. Fig. 3 A shows a representative plot of the protective effect of prior incubation with AG-126 on survival of U937 cells exposed to menadione. Cell death reached $95 \%$ after exposure to $30 \mu \mathrm{M}$ menadione, but declined to $55 \%$ when cells were pretreated with $25 \mu \mathrm{M}$ AG-126 for $14 \mathrm{~h}$. Menadione toxicity on U937 cells was quantified by calculating its median-effect concentration $\left(D_{m}\right)$ upon 5-h exposure (Fig. 3 B) was 13.3 $\pm 1.9 \mu \mathrm{M}$. Interestingly, prior incubation of U937 cells with AG-126 for 6,14 or $22 \mathrm{~h}$ caused a $\mathrm{D}_{\mathrm{m}}$ increase of 34,66 or $68 \%$, respectively. U937 cells were also pretreated with different BMN compounds $(25 \mu \mathrm{M})$ for $14 \mathrm{~h}$ prior to exposure to menadione for $5 \mathrm{~h}$. Even though they are structurally different from AG-126, EMK 121 and EMK 201 had a similar protective effect whereas BMN compounds with MeO substitutions (EMK 041, EMK 131, EMK 721, EMK 731, EMK 841) (Table 2) were weaker protectors. Subsequent analysis revealed a significant correlation between 
HO-1 induction and the protective properties of the analyzed BMN compounds. Pearson correlation coefficients $\left(\rho_{\mathrm{X}, \mathrm{Y}}\right)$ between Dm increase and induction of HO-1 at the mRNA and protein levels, were $0.683(n=12)$ and $0.784(n=9)$, respectively, and the linear correlation coefficients $\left(\mathrm{R}^{2}\right)$ were $0.467(p<0.02)$ and $0.615(p<0.02)$, respectively (Fig. 3, C and D).

\subsection{Spectroscopic evidence for reactivity of $A G-126$ with $G S H$}

In cells of different types, activation of redox-sensitive signaling pathways is triggered mainly by modification of sensitive cysteine residues on specific cellular targets. It was shown that chlorobenzylidene malononitriles referred to in this study as EMK 531 and EMK 611 conjugate with GSH, the most abundant cellular thiol compound [17]. UV-Vis spectrum of AG-126 (50 $\mu \mathrm{M})$ with $\mathrm{GSH}(1 \mathrm{mM})$ in $50 \mathrm{mM}$ Tris $\mathrm{HCl}$ buffer (pH 7.4) showed a slight hypsochromic shift from 281 to $278 \mathrm{~nm}$ with concomitant increase of intensity of the absorption maximum (Fig. 4). These spectral alterations suggest that AG-126 forms a conjugate with GSH.

\subsection{Correlations between chemical activity of BMN compounds and HO-1 mRNA induction.}

The reactivity of some BMNs and related Michael acceptors toward thiols has previously been studied $[17,18]$. The reaction proceeds via a fast reversible addition of a thiol to the conjugated system. Equilibrium constants for reactions with $n$-butanethiol of BMN derivatives referred here to as EMK 031, EMK 721, AG-9, EMK 081, EMK 471, EMK 491, EMK 191, EMK 231, EMK 621, EMK 441, EMK 531, EMK 151, and EMK 121 range from 0.13 to $12.0 \times 10^{2}\left(\mathrm{M}^{-1}\right)\left(25^{\circ} \mathrm{C}\right.$, $\mathrm{pH}$ 7.0) [18]. We analyzed the correlation between BMN reaction rates with thiols by plotting the equilibrium constant for the reactions between BMNs and $n$-butanethiol [18] versus the capacity to induce HO-1 gene expression (our data from Table 1). As shown in Fig. 5A, there is a clear correlation between these two parameters $\left(R^{2}=0.674, \rho_{X, Y}=0.821, n=14\right)$.

Moreover, as shown in Fig. 5B, there is a positive correlation between the hydrolysis rate of BMNs [19] and the capacity to induce HO-1 mRNA expression $\left(\mathrm{R}^{2}=0.742, \rho_{\mathrm{X}, \mathrm{Y}}=0.861, \mathrm{n}=\right.$ 
12). Calculated half-lives of these BMN compounds in aqueous solution range from 2.5 min to

38.3 h. Surprisingly, the short lifespan of BMN compounds in water did not reduce their capacity to induce HO-1 mRNA. Thus, the compounds with a short half-life such as EMK 121, EMK 151 and EMK 531 (calculated $t_{1 / 2}=2.5,3.2$ and $9.7 \mathrm{~min}$, respectively) were the most effective activators of HO-1 gene expression.

\subsection{LC-MS analysis of BMN adducts with GSH}

In order to further characterize GSH conjugates with BMNs, we analyzed the reaction mixtures of a selection of BMNs with reduced GSH $\left(1 \mathrm{~h}, 25^{\circ} \mathrm{C}\right)$ by LC-MS using electrospray ionization (ESI) in positive and negative mode. The compounds tested (AG-126, EMK 131, EMK 721, EMK 731, and EMK 1071) were selected because they differently stimulate HO-1 expression and activate upstream signaling systems (Table 1). As shown in Fig. 6A, evaporative light scattering detector (ELSD) revealed a single product of the reaction between AG-126 and GSH eluting at $1.50 \mathrm{~min}$. Detailed ESI-MS2- analysis produced a peak with an $\mathrm{m} / \mathrm{z}$ value of 828.5 , corresponding to the conjugate of AG-126 with two equivalents of GSH and gave rise to fragments at 521 (R-GSH) and 306 (GSH). The thiophene malononitrile EMK 1071, after reaction with GSH, produced a compound with an ELSD retention time of $2.00 \mathrm{~min}$. ESI-MS2analysis showed two major peaks corresponding to the mono- and di-charged ions (482.2 and 241.7), suggesting that this compound reacts with a single molecule of GSH (Fig. 6B). Likewise, reaction of EMK $131\left(3,4-(\mathrm{MeO})_{2} \mathrm{BMN}\right)$ with $\mathrm{GSH}$, gave a single product with elution retention time of $1.64 \mathrm{~min}$. ESI-MS2 analysis revealed an $\mathrm{m} / \mathrm{z}$ value of 827.5 corresponding to conjugate between EMK 131 and two GSH (Fig. 6C). As regards EMK 721 (2,4-(MeO) 2 BMN), ELSD analysis detected a single product resulting from conjugation of one GSH and one EMK 721 molecule $(\mathrm{m} / \mathrm{z}=522.2)$ (Fig. 6D). Lastly, the reaction between EMK $731\left(3,4-(\mathrm{MeO})_{2} \mathrm{BMN}\right)$ and GSH generated two products with elution retention time of 1.4 and 1.9 min consistent with the addition of two $(\mathrm{m} / \mathrm{z}=829.4)$ and one $(\mathrm{m} / \mathrm{z}=522.3)$ molecule(s) of GSH to one molecule of 
EMK 731, respectively (Fig. 6E). It is worth noting that LC-MS analysis performed after 1-h and 24-h incubation of AG-126 with GSH revealed the same composition of the reaction mixture (data not shown), suggesting that these conjugates of BMN with GSH are thermodynamically stable.

\section{Discussion}

In a previous study, we showed that BMN compounds are potent activators of HO-1 expression [11]. Thus, in U937 cells exposed to AG-126, the level of HO-1 mRNA increased to more than 300 times the basal level, as compared with the synthetic triterpenoid CDDO-imidazolide which stimulates HO-1 mRNA expression 90-fold [20]. Here, we point to a significant correlation between BMN-mediated HO-1 induction and decrease in menadione-induced toxicity, suggesting that HO-1 up-regulation is an indicator of drug efficacy. In addition, our investigation of the structure-activity relationship of $49 \mathrm{BMNs}$ points out structure substitutions that determine specific responsiveness of major signaling pathways.

HO-1 gene expression is activated mainly at the transcriptional level in various cell types by a broad spectrum of chemical and physical agents including heat shock, ultraviolet light, hypoxia, cytokines, reactive oxygen and nitrogen species, and xenobiotics $[21,22]$. The regulation of HO1 expression is mediated by a complex network of transcriptional regulators acting on many responsive elements located in the promoter region of the HO-1 gene: antioxidant response element (ARE), Maf recognition element (MARE), hypoxia response elements (HREs), heat shock element (HSE), and multiple binding sites for transcription factors AP-1, C/EBP, STAT, and NF- $\mathrm{NB}$. In brief, the master regulator Nrf2 plays a central role in induction of $\mathrm{HO}-1$ in partnership with other transcription factors including small Maf proteins, c-Jun and ATF4 [2326]. 
Our structure-activity relationship analysis shows that BMN compounds have different structural requirements for activation of $\mathrm{Nrf} 2$ and c-Jun cellular signaling pathways (Table 1). It is interesting to note that with the exception of EMK 841, none of the 14 BMNs displaying either Nrf2 or p-c-Jun low expression $(\mathrm{FC} \leq 1.7)$ was found to elicit robust $(\mathrm{FC}>10) \mathrm{HO}-1 \mathrm{mRNA}$ induction (Table 1). These observations suggest that the parallel increase in cellular Nrf2 and pc-Jun is a prerequisite for full-scale HO-1 gene induction by BMNs. This assertion is supported by our previous observation that U937 cell treatment with tyrphostin AG-126 and synthetic NO donor DPTA-NO, a potent c-Jun activator, had a cumulative effect on expression of the ferritin H and IL-8 genes [11] which, like HO-1, are under the control of Nrf2/ARE and AP-1 signaling $[27,28]$. Nrf2/ARE signaling can be activated through Nrf2 phosphorylation by MAP kinases and other regulatory protein kinases that facilitate $\mathrm{Nrf} 2$ nuclear translocation $[29,30]$. It is therefore possible that HO-1 induction by BMN compounds is mediated by JNK-dependent phosphorylation of Nrf2, as previously shown for PC-3 cells exposed to isothiocyanates [29]. As summarized in the scheme proposed in Fig. 6, interplay between different signaling networks shows that the BMN-induced activation of HO-1 expression can be explained by the binding of the Nrf2-c-Jun complex to ARE regulatory sequences located in the enhancer region $[29,30]$.

Nrf2 functional activity is regulated negatively by Keap1, a cytoplasmic factor that binds Nrf2 and the actin cytoskeleton, and has ubiquitin ligase adaptor activity. Association of Keap1 with Nrf2 retains the latter in the cytoplasm and promotes its rapid proteosomal degradation. Keap1 contains several critical thiol groups, particularly $\mathrm{Cys}^{151}, \mathrm{Cys}^{273}, \mathrm{Cys}^{278}$, and their oxidation by reactive oxygen species or alkylation by electrophiles enables dissociation and nuclear translocation of Nrf2 [31-34]. Chemical substances activating Keap1/Nrf2 pathway were classified by Talalay and co-workers as 10 distinct groups that include quinones, isothiocyanates, dimercaptans, heavy metals, and various Michael reaction acceptors like olefins conjugated to electron-withdrawing groups $[35,36]$. A common feature of these structurally different compounds is their high reactivity with sulfhydryl groups. 
Our results indicate that potency of BMN compounds to induce HO-1 mRNA induction is

related to their properties of Michael reaction acceptors. Thus, the presence of two strong electron-withdrawing $\mathrm{CN}$ groups conjugated to a $\mathrm{C}=\mathrm{C}$ bond, is a critical requirement for transcriptional activation of HO-1 gene. Furthermore, our data showing that reactivity of BMNs and related Michael acceptors with thiols is correlated with their capacity to induce HO-1 expression, suggest that BMN compounds can modify Keap1 and others cytoplasmic regulatory factors by linking to their critical protein sulfhydryl groups. Binding to Keap-1 would promote release and translocation of Nrf2 to the nucleus where it forms heterodimers with partner proteins (e.g. c-Jun), binds to the ARE, and activate gene expression. In addition, our finding that BMN reactivity with GSH correlates with the rate of $\mathrm{HO}-1$ mRNA induction is in good agreement with previous results obtained by Talalay's group showing that the reactivity of benzylideneketone acceptors with sulfhydryl reagents is the major factor that determines their potency to induce cell protective genes [36]. Further, a quantum chemical study established significant structure-activity relationships between electron-acceptor properties of triterpenoids and their biological potencies [37].

LC-MS analysis revealed that reaction of GSH with BMN compounds could generate two types of conjugates, one with two GSH molecules and another with one GSH molecule. Remarkably, AG-126 and EMK 131 which generate di(GSH) conjugates, induced HO-1 mRNA expression and c-Jun activation more potently than EMK 721, EMK 1071, and EMK 731 which generate mono-GSH conjugates. The ability of several BMN compounds to generate conjugates with two GSH equivalents suggests they can yield intra- or inter-molecular bridges between low- or highmolecular weight thiols. It is tempting to speculate that GSH, the most abundant cellular thiol, may serve as a carrier molecule for BMNs, protecting them from a simple hydrolysis, and liberating them upon cell demands.

A large body of experimental data shows that under physiological conditions, BMN compounds are able to stimulate the resistance of cells and tissues against different harmful challenges. For 
example, tyrphostin AG-1714 (4-nitrobenzylidene malononitrile, referred to here as EMK 121)

provides significant protection against mortality induced by chemotherapy with cisplatin and doxorubicin in animals and in cell cultures [7]. Remarkably, AG-1714 stimulates resistance of healthy tissues to chemotherapy without protecting malignant tissues against drug-mediated suppression [7]. This selectivity may be associated with increased basal HO-1 expression in various tumor cells [22]. Experiments performed in vivo showed that tyrphostin AG-126 reduced development of pneumococcal meningitis, kidney acute injury and dysfunction after ischemia and reperfusion, development of acute pancreatitis, consequences of spinal cord trauma, and mitochondria-mediated 7-ketocholesterol toxicity [6, 10, 38-41]. Our findings that BMN compounds are activators of cell protection may provide clues to development of new drugs that mimic the protective response.

In conclusion, our study discloses that full activation of HO-1 expression by BMNs requires parallel up-regulation of two major signaling pathways, the Nrf2/Keap-1 system and the cJun/JNK pathway. This finding provides a possible tool for pharmacological modulation of intercellular signaling. Many short-distance signaling molecules like prostaglandins, NO, regulatory peptides, and cytokines activate JNK MAP kinases and c-Jun phosphorylation. It is thus likely that BMN compounds dedicated to Nrf2 activation will up-regulate protective systems exclusively in tissues that produce c-Jun-activating signaling molecules. According to these guidelines, the most suitable molecules are 4-morphlino BMN (EMK 251), 4-OH BMN (AG-10, EMK 031, EMK 071) and thiophene malononitrile EMK 1071. However, a potential drawback of AG-10 is its adverse effect, as a phenolic compound, on mitochondrial membrane polarity [3]. Nonetheless, because of the different capacities of BMN hydrolysis products to cross membranes, we suggest that BMNs chiefly react with molecular targets located in proximity to vasculature. 


\section{Acknowledgments}

This work was supported by funding from CNRS. We thank Odile Thoison for discussion and help with performing LC/MS analyses and Geneviève Aubert for excellent technical assistance.

\section{References}

[1] Levitzki A. Tyrphostins, tyrosine kinase blockers as novel antiproliferative agents and dissectors of signal transduction. FASEB J 1992; 6: 3275-82.

[2] Levitzki A, Mishani E. Tyrphostins and other tyrosine kinase inhibitors. Annu Rev Biochem 2006, 75: 93-109.

[3] Sagara Y, Ishige K, Tsai C, Maher P. Tyrphostins protect neuronal cells from oxidative stress, J Biol Chem 2002; 277: 36204-15.

[4] Soltoff SP. Evidence that tyrphostins AG10 and AG18 are mitochondrial uncouplers that alter phosphorylation-dependent cell signaling. J Biol Chem 2004; 279:10910-8.

[5] Novogrodsky A, Vanichkin A, Patya M, Gazit A, Osherov N, Levitzki A. Prevention of lipopolysaccharide-induced lethal toxicity by tyrosine kinase inhibitors. Science $1994 ; 264: 1319$ 22.

[6] Hanisch UK, Prinz M, Angstwurm K, Häusler KG, Kann O, Kettenmann H, Weber JR. The protein tyrosine kinase inhibitor AG126 prevents the massive microglial cytokine induction by pneumococcal cell walls. Eur J Immunol 2001; 31: 2104-15.

[7] Novogrodsky A, Weisspapir M, Patya M, Meshorer A, Vanichkin A. Tyrphostin 4nitrobenzylidene malononitrile reduces chemotherapy toxicity without impairing efficacy. Cancer Res 1998; 58:2397-403.

[8] Vanichkin A, Patya M, Lagovsky I, Meshorer A, Novogrodsky A. 4-Nitrobenzylidene malononitrile reduces apoptosis-mediated liver injury in mice. J Hepatol 2002; 36:631-6. 
[9] Kann O, Hoffmann A, Schumann RR, Weber JR, Kettenmann H, Hanisch UK. The tyrosine kinase inhibitor AG126 restores receptor signaling and blocks release functions in activated microglia (brain macrophages) by preventing a chronic rise in the intracellular calcium level, $\mathrm{J}$ Neurochem 2004; 90:513-25.

[10] Chatterjee PK, Patel NS, Kvale EO, Brown PA, Stewart KN, Britti D, Cuzzocrea S, MotaFilipe H, Thiemermann C. The tyrosine kinase inhibitor tyrphostin AG126 reduces renal ischemia/reperfusion injury in the rat. Kidney Int 2003; 64: 1605-19.

[11] Turpaev K, Drapier JC. Stimulatory effect of benzylidenemalononitrile tyrphostins on expression of NO-dependent genes in U-937 monocytic cells. Eur J Pharmacol 2009; 606:1-8.

[12] Kunnumakkara AB, Anand P, Aggarwal BB. Curcumin inhibits proliferation, invasion, angiogenesis and metastasis of different cancers through interaction with multiple cell signaling proteins. Cancer Lett 2008; 269:199-225.

[13] Sporn MB, Suh N. Chemoprevention: an essential approach to controlling cancer. Nat Rev Cancer 2002;2:537-43.

[14] Harper DAR, Steenson BE. Preparation of $\alpha, \beta$-unsaturated sulfones by the Knoevenagel method. Synthesis 1980; 806-807.

[15] Bumagin NA, Andryukhova NP, Beletskaya IP. Arylation of acrylonitrile with aryl halides catalyzed by palladium complexes. Dokl Akad Nauk SSSR 1990; 313:107-9.

[16] Chou TC, Talalay P. Quantitative analysis of dose-effect relationships: the combined effects of multiple drugs or enzyme inhibitors. Adv Enzyme Regulation 1984; 22:27-55.

[17] Rietveld EC, Hendrikx MM, Seutter-Berlage F. Glutathione conjugation of chlorobenzylidene malononitriles in vitro and the biotransformation to mercapturic acids in rats. Arch Toxicol 1986; 59:228-34.

[18] Pritchard RB, Lough CE, Currie DJ, Holmes HL. Equilibrium reactions of n-butanethiol with some conjugated heteroenoid compounds. Can J Chem 1968; 46:775-81. 
[19] Pritchard RB, Lough CE, Reesor JB, Holmes HL, Currie DJ. The relative rates of reaction of potassium cyanide and water with substituted benzalmalononitriles. Can J Chem 1967; 45:775-77.

[20] Liby K, Hock T, Yore MM, Suh N, Place AE, Risingsong R, Williams CR, Royce DB, Honda T, Honda Y, Gribble GW, Hill-Kapturczak N, Agarwal A, Sporn MB. The synthetic triterpenoids, CDDO and CDDO-imidazolide, are potent inducers of heme oxygenase-1 and Nrf2/ARE signaling. Cancer Res 2005;65:4789-98.

[21] Ryter SW, Alam J, Choi AM. Heme oxygenase-1/carbon monoxide: from basic science to therapeutic applications. Physiol Rev 2006; 86: 583-650.

[22] Was H, Dulak J, Jozkowicz A. Heme oxygenase-1 in tumor biology and therapy. Curr Drug Targets 2010; 11:1551-70.

[23] Copple IM, Goldring CE, Kitteringham NR, Park BK. The Nrf2-Keap1 defense pathway: role in protection against drug-induced toxicity. Toxicology 2008; 246:24-33.

[24] Levy S, Jaiswal AK, Forman HJ. The role of c-Jun phosphorylation in EpRE activation of phase II genes. Free Radic Biol Med 2009;47:1172-9.

[25] Jaiswal AK. Nrf2 signaling in coordinated activation of antioxidant gene expression. Free Radic Biol Med 2004; 36:1199-207.

[26] Lee AC, Murray M. Up-regulation of human CYP2J2 in HepG2 cells by butylated hydroxyanisole is mediated by c-Jun and Nrf2. Mol Pharmacol 2010; 77:987-94.

[27] Pietsch EC, Chan JY, Torti FM, Torti SV. Nrf2 mediates the induction of ferritin H in response to xenobiotics and cancer chemopreventive dithiolethiones. J Biol Chem 2003; 278:2361-9.

[28] Loboda A, Stachurska A, Florczyk U, Rudnicka D, Jazwa A, Wegrzyn J, Kozakowska M, Stalinska K, Poellinger L, Levonen AL, Yla-Herttuala S, Jozkowicz A, Dulak J. HIF-1 induction attenuates Nrf2-dependent IL-8 expression in human endothelial cells. Antioxid Redox Signal 2009; 11:1501-17. 
[29] Xu C, Yuan X, Pan Z, Shen G, Kim JH, Yu S, Khor TO, Li W, Ma J, Kong AN. Mechanism of action of isothiocyanates: the induction of ARE-regulated genes is associated with activation of ERK and JNK and the phosphorylation and nuclear translocation of Nrf2. Mol Cancer Ther 2006; 5:1918-26.

[30] Anwar AA, Li FY, Leake DS, Ishii T, Mann GE, Siow RC. Induction of heme oxygenase 1 by moderately oxidized low-density lipoproteins in human vascular smooth muscle cells: role of mitogen-activated protein kinases and Nrf2. Free Radic Biol Med 2005; 39:227-36.

[31] Sekhar KR, Rachakonda G, Freeman ML. Cysteine-based regulation of the CUL3 adaptor protein Keap1. Toxicol Appl Pharmacol 2010;244:21-6.

[32] Dinkova-Kostova AT, Holtzclaw WD, Kensler TW. The role of Keap1 in cellular protective responses. Chem Res Toxicol 2005; 18:1779-91.

[33] Wakabayashi N, Dinkova-Kostova AT, Holtzclaw WD, Kang MI, Kobayashi A, Yamamoto M, Kensler TW, Talalay P. Protection against electrophile and oxidant stress by induction of the phase 2 response: fate of cysteines of the Keap1 sensor modified by inducers. Proc Natl Acad Sci U S A 2004; 101:2040-5.

[34] Fourquet S, Guerois R, Biard D, Toledano MB. Activation of NRF2 by nitrosative agents and $\mathrm{H}_{2} \mathrm{O}_{2}$ involves KEAP1 disulfide formation. J Biol Chem 2010; 285:8463-71.

[35] Dinkova-Kostova AT, Fahey JW, Talalay P. Chemical structures of inducers of nicotinamide quinone oxidoreductase 1 (NQO1). Methods Enzymol 2004; 382:423-48.

[36] Dinkova-Kostova AT, Massiah MA, Bozak RE, Hicks RJ, Talalay P. Potency of Michael reaction acceptors as inducers of enzymes that protect against carcinogenesis depends on their reactivity with sulfhydryl groups. Proc Natl Acad Sci U S A 2001; 98:3404-9.

[37] Bensasson RV, Zoete V, Berthier G, Talalay P, Dinkova-Kostova AT. Potency ranking of triterpenoids as inducers of a cytoprotective enzyme and as inhibitors of a cellular inflammatory response via their electron affinity and their electrophilicity index. Chem Biol Interact 2010; $186: 118-26$. 
[38] Gonçalves S, Fernandez-Sanchez R, Sanchez-Niño MD, Tejedor A, Neria F, Egido J, RuizOrtega M, Ortiz A. Tyrphostins as potential therapeutic agents for acute kidney injury. Curr Med Chem 2010; 17:974-86.

[39] Balachandra S, Genovese T, Mazzon E, Di Paola R, Thiemerman C, Siriwardena AK, Cuzzocrea S. Inhibition of tyrosine-kinase-mediated cellular signaling by tyrphostins AG 126 and AG556 modulates murine experimental acute pancreatitis. Surgery 2005; 138:913-23. [40] Genovese T, Mazzon E, Esposito E, Muià C, Di Paola R, Crisafulli C, Bramanti P, Cuzzocrea S. Inhibition of tyrosine kinase-mediated cellular signalling by Tyrphostins AG126 and AG556 modulates secondary damage in experimental spinal cord trauma. Neuropharmacology 2007; 52:1454-71.

[41] Kim YJ, Lee CS. Tyrosine kinase inhibitor AG126 reduces 7-ketocholesterol-induced cell death by suppressing mitochondria-mediated apoptotic process. Neurochem Res 2010; 35:60312. 


\section{Legends to figures}

Fig. 1. HO-1 expression in U937 cells exposed to AG-126. Dose dependence (A), time-course (B) for HO-1 mRNA accumulation and time-course of HO-1 protein accumulation (C). U937 cells were incubated with $25 \mu \mathrm{M}$ AG-126 for the indicated times (B, and C) or for $3 \mathrm{~h}$ at the indicated concentrations (A). Each bar represents the mean \pm SD of at least three independent experiments. HO-1 mRNA and protein levels in untreated cells were assigned a value of 1.

Fig. 2. Activation of signaling systems by selected BMNs or structurally similar compounds. (A) Representative Western blot image. U937 cells were incubated with BMNs $(25 \mu \mathrm{M})$ for $3 \mathrm{~h}$. Whole cell lysates were analyzed by immunoblotting with Nrf2, phospho-cJun, phospho-p38, phospho-p70S6K, and $\beta$-actin antibodies. (B) Relative induction of HO-1 mRNA plotted against Nrf2 level. (C) Relative induction of HO-1 mRNA plotted against p-c-Jun level. Western blot or RT-PCR quantification data of three independent experiments are shown. HO-1 mRNA and protein levels in untreated cells were assigned a value of 1.

Fig. 3. Protective effects of BMNs upon oxidative stress. (A) Fraction of necrotic cells (Fa) plotted against menadione concentration. Cells were exposed to menadione for $5 \mathrm{~h}$ after being pre-treated or not with $25 \mu \mathrm{M}$ AG-126 (14h). (B) Analysis of the above data by the median effect plot. Fu is the fraction of unaffected cells. The results are analyzed by plotting $\log (\mathrm{Fa} / \mathrm{Fu})$ with respect to $\log$ of menadione concentration $(0-60 \mu \mathrm{M})$. (C) Correlations between HO-1 mRNA accumulation or (D) HO-1 protein content and the median concentration values $\left(\mathrm{D}_{\mathrm{m}}\right)$ of BMNs (12 and 9 compounds for $\mathrm{C}$ and $\mathrm{D}$, respectively). Dm is the concentration of menadione required to produce a $50 \%$ toxic effect, i.e., when $\mathrm{Fa}=\mathrm{Fu}$. Each $\mathrm{Dm}$ value represents the mean of three independent experiments. 
Fig. 4. Spectrophotometric analysis of AG-126 reaction with GSH. AG-126 (50 $\mu \mathrm{M})$ was incubated with (dotted line) or without (solid line) $1 \mathrm{mM}$ GSH in $50 \mathrm{mM}$ Tris- $\mathrm{HCl}$ buffer containing 5\% of DMSO ( $\mathrm{pH} 7.5)$ for $1 \mathrm{~h}$ at room temperature.

Fig. 5. Correlation between HO-1 gene expression and chemical properties of BMN compounds. The relative levels of HO-1 mRNA (data from Table 1) were plotted against equilibrium constants $\left(K_{\mathrm{eq}} \times 10^{-2}\right)$ for reactions with $n$-butanethiol [18] (A) and BMN hydrolysis first-order constants $\left(k_{\mathrm{H} 2 \mathrm{O}} \times 10^{4}\right)[19](\mathrm{B})$.

Fig. 6. LC-MS analysis of adducts between GSH and BMNs. ELSD chromatograms and subsequent ESI-MS2 analysis of the reaction products. Bottom panels compare the experimental $\mathrm{m} / \mathrm{z}$ and calculated MW values of initial compounds and expected GSH conjugates. Compounds were incubated with $5 \mathrm{mM}$ GSH in $50 \mathrm{mM}$ Tris-HCl buffer containing $10 \%$ of $\mathrm{MeOH}(\mathrm{pH} 7.5)$ for $1 \mathrm{~h}$ at room temperature. The incubation of AG-126 (A) and EMK 1071 (B) with GSH resulted in generation of single ELSD detectable products with retention time 1.50 and 2.00 min, respectively. ESI-MS2 analyses suggest that AG-126 conjugates with two GSH equivalents whereas EMK 1071 conjugates with one GSH molecule. The product of EMK 131 (C) and EMK 721 (D) reactions with GSH were revealed as a single peaks (ELSD retention times 1.64 and $2.20 \mathrm{~min}$, respectively) corresponding to BMN adducts with a one molecule of GSH. The incubation of EMK 731 (E) with GSH resulted in the generation of two products revealed by ELSD as peaks at retention times of 1.37 and $1.91 \mathrm{~min}$. ESI-MS2 analysis suggests that the first peak corresponds to EMK 731 conjugated with two GSH equivalents whereas the second one corresponds to EMK 731 conjugate with a single GSH molecule. 
Fig. 7. Scheme of a proposed mechanism of BMN-dependent signaling and regulation of HO-1 gene expression. In the absence of BMN, the thiol-rich sensor protein Keap1 retains Nrf2 in the cytoplasm where it is targeted for ubiquity-mediated degradation. BMN compounds alkylate reactive SH-groups of Keap1 resulting in Nrf2 dissociation, nuclear translocation and binding to ARE regulatory elements in heteromeric combination with bZIP family transcription factors (cJun, small Maf proteins, ATF4). In parallel, BMN compounds can modify other regulatory proteins, resulting in up-regulation of MAP kinases and AP-1 family transcription factors. MAP kinases can regulate Nrf2 stability and induce gene expression via the AP-1 binding sites TPAresponsive element (TRE) and c-AMP-responsive element (CRE). Multiple copies of AP-1 binding sites are present in the regulatory region of HO-1 gene. 
Table 1. BMN compounds examined in this study. Structure and potency to induce HO-1 and to activate Nrf2 and c-Jun.

\begin{tabular}{|c|c|c|c|c|c|}
\hline \multicolumn{2}{|c|}{ Compounds } & \multicolumn{4}{|c|}{ Induction/activation (Fold-Change) } \\
\hline code & structure & $\begin{array}{c}\text { HO-1 } \\
\text { mRNA }\end{array}$ & $\begin{array}{c}\text { HO-1 } \\
\text { protein }\end{array}$ & Nrf2 & p-cJun \\
\hline AG-9 & & 76.3 & ND & 8.7 & 3.5 \\
\hline AG-10 & & 28.3 & ND & 8.2 & 2.2 \\
\hline AG-126 & & 307.1 & 8.4 & 13.1 & 5.5 \\
\hline EMK 031 & & 9.4 & ND & 5.0 & 1.3 \\
\hline EMK 041 & & 123.0 & 6.3 & 5.7 & 2.1 \\
\hline EMK 071 & & 4.1 & ND & 7.4 & 0.9 \\
\hline EMK 081 & & 165.7 & 8.0 & 9.2 & 2.5 \\
\hline EMK 091 & & 127.9 & ND & 8.7 & 3.5 \\
\hline EMK 121 & & 309.7 & ND & 15.8 & 13.2 \\
\hline EMK 131 & & 243.4 & ND & 8.2 & 8.5 \\
\hline EMK 151 & & 283.6 & 9.0 & 13.5 & 13.8 \\
\hline EMK 161 & & 163.0 & ND & 9.6 & 3.4 \\
\hline EMK 171 & & 118.3 & ND & 5.5 & 5.0 \\
\hline EMK 181 & & 133.5 & ND & 8.8 & 2.8 \\
\hline
\end{tabular}


EMK 191

EMK 201

EMK 211

EMK 221

EMK 231

EMK 241

EMK 251

EMK 281

EMK 301

EMK 311

EMK 321

EMK 381

EMK 421

EMK 431

EMK 441

EMK 461

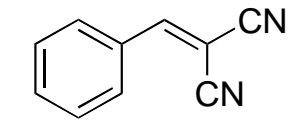<smiles>N#CC(C#N)=Cc1ccc(F)c(O)c1</smiles><smiles>N#CC(C#N)=Cc1ccc(O)c(F)c1</smiles><smiles>N#CC(C#N)=Cc1cccc(F)c1</smiles><smiles>COc1cccc(C=C(C#N)C#N)c1</smiles><smiles>CC(C)(C)c1ccc(C=C(C#N)C#N)cc1</smiles><smiles>CCCCCCNc1ccc(C=C(C#N)C#N)cc1</smiles><smiles>O=CO</smiles><smiles>CCOC(=O)/C(C#N)=C/c1cccc([N+](=O)[O-])c1</smiles><smiles>CCOC(=O)C(=Cc1cccc([N+](=O)[O-])c1)S(C)(=O)=O</smiles><smiles>COS(=O)(=O)C(C#N)=Cc1cccc([N+](=O)[O-])c1</smiles><smiles>O=[N+]([O-])/C=C/c1cccc([N+](=O)[O-])c1</smiles>

1.0

169.5

246.4

276.3

232.3

153.5

4.5

188.1

135.7

81.3

10.0

145.4

7.7

1.6

1.0<smiles>Cc1ccccc1C=C(C#N)C#N</smiles><smiles>N#CC(C#N)=Cc1ccccc1N</smiles><smiles>N#CC(C#N)=Cc1ccccc1F</smiles>

ND

12.9

ND

7.8

ND

4.0

1.4

5.4

6.4

ND

5.8

ND

8.9

ND

9.7

1.1

7.0

12.4

12.8

ND

1.5

8.8

ND

1.7

6.4

$1.3 \quad$ ND

1.1

1.9

ND

1.0

1.5

9.6

7.0

3.6

8.3

ND

ND

12.1

6.5

4.0<smiles>N#CC(C#N)=Cc1ccccc1Br</smiles>

5.7

11.5

29.6 
EMK 471

EMK 491

EMK 511

EMK 531

EMK 591

EMK 611

EMK 621

EMK 661

EMK 711

EMK 721

EMK 731

EMK 841

EMK 851

EMK 861

EMK 871

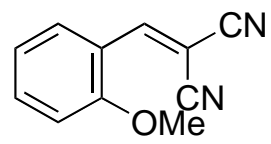

93.2<smiles>N#C/C(=C/c1ccccc1[N+](=O)[O-])[N+](=O)[O-]</smiles><smiles>N#CC(C#N)=Cc1cccc(C#N)c1</smiles><smiles>N#CC(C#N)=Cc1cccc(Cl)c1</smiles><smiles>N#CC(C#N)=Cc1ccc(C#N)cc1</smiles><smiles>N#CC(C#N)=Cc1ccc(Cl)cc1</smiles>

ND<smiles>N#CC(C#N)=Cc1ccc(Br)cc1</smiles><smiles>C/C(C#N)=C/c1ccc(C(F)(F)F)cc1</smiles>

ND<smiles>COc1cccc(C=C(C#N)C#N)c1OC</smiles>
OMe<smiles>COc1ccc(C=C(C#N)C#N)c(OC)c1</smiles>

25.7<smiles>COc1ccc(C=C(C#N)C#N)cc1OC</smiles>

$\mathrm{OMe}$<smiles>COc1ccc(C=C(C#N)C#N)c(OC)c1OC</smiles><smiles>COc1cc(C=C(C#N)C#N)cc(C)c1OC</smiles><smiles>COc1cc(OC)c(C=C(C#N)C#N)c(OC)c1</smiles>

270.6

260.6

272.5

136.

31.3

40.4

2.1

2.0 $\begin{array}{ll}6.8 & 6.4\end{array}$

245.5

9.1

4.8

7.2

10.9

ND

ND

11.5

ND

ND

14.2

240.5

6.0

4.8

9.4

4.3

9.6

4.5

ND

5.3

$\begin{array}{lll}36.4 & 9.6\end{array}$

2.9

4.3

1.3

.6

$\begin{array}{lll}4.1 & 4.8 & 1.6\end{array}$

6.3

4.2

1.2

4.0

3.5

1.5

1.3

2.1

1.1 
EMK 991<smiles>N#CC(C#N)=Cc1ccc2ccccc2c1</smiles>

EMK 1041<smiles>N#CC(C#N)=Cc1ccnc2ccccc12</smiles>

EMK 1051<smiles>N#CC(C#N)=Cc1c[nH]c2ccccc12</smiles>

ND

6.9

ND

ND

7.1

5.0

ND

40.5

U937 cells were exposed to the indicated chemicals $(25 \mu \mathrm{M})$ for $3 \mathrm{~h}$. Relative mRNA and protein levels were measured by RT-PCR and Western blotting, respectively. The mRNA and protein (phosphoprotein) levels in untreated cells were assigned a value of 1 . Data represent the mean of at least three independent experiments. BMN compounds referred to here as EMK 031, EMK 041, EMK 071, EMK131, and EMK 251 are also known as tyrphostins A16, A15, A19, A2, and A6, respectively [14]. ND, not done. 
Table 2. Protective effects of BMN compounds upon menadione toxicity.

\begin{tabular}{ccc}
\hline Compounds & $\mathrm{D}_{\mathrm{m}}( \pm \mathrm{SD})$ & $\mathrm{D}_{\mathrm{m}}$ increase $(\mu \mathrm{M})$ \\
\hline AG-126 & $24.4 \pm 2.5$ & 11.1 \\
EMK 041 & $20.0 \pm 2.2$ & 6.7 \\
EMK 081 & $23.0 \pm 2.3$ & 9.7 \\
EMK 121 & $25.2 \pm 2.7$ & 11.9 \\
EMK 131 & $19.9 \pm 2.1$ & 6.6 \\
EMK 151 & $19.6 \pm 2.2$ & 6.3 \\
EMK 201 & $23.4 \pm 2.4$ & 10.1 \\
EMK 281 & $20.3 \pm 1.9$ & 7.0 \\
EMK 721 & $16.2 \pm 1.8$ & 2.9 \\
EMK 731 & $18.1 \pm 2.5$ & 4.8 \\
EMK 841 & $20.8 \pm 2.0$ & 7.5 \\
EMK 1071 & $18.4 \pm 1.9$ & 5.1 \\
\hline
\end{tabular}

U937 cells were exposed or not to the indicated BMN compounds $(25 \mu \mathrm{M})$ for $14 \mathrm{~h}$ prior to treatment with menadione $(0-60 \mu \mathrm{M})$ for an additional 5-h period. The data are expressed as the variation of the median-effect concentration $\left(D_{m}\right)$ in $B M N$ preconditioned cells relative to untreated cells, and are the mean of at least three independent experiments. The $\mathrm{D}_{\mathrm{m}}$ value for cells exposed to menadione alone was $13.3 \pm 1.9 \mu \mathrm{M}$. 
Fig. 1

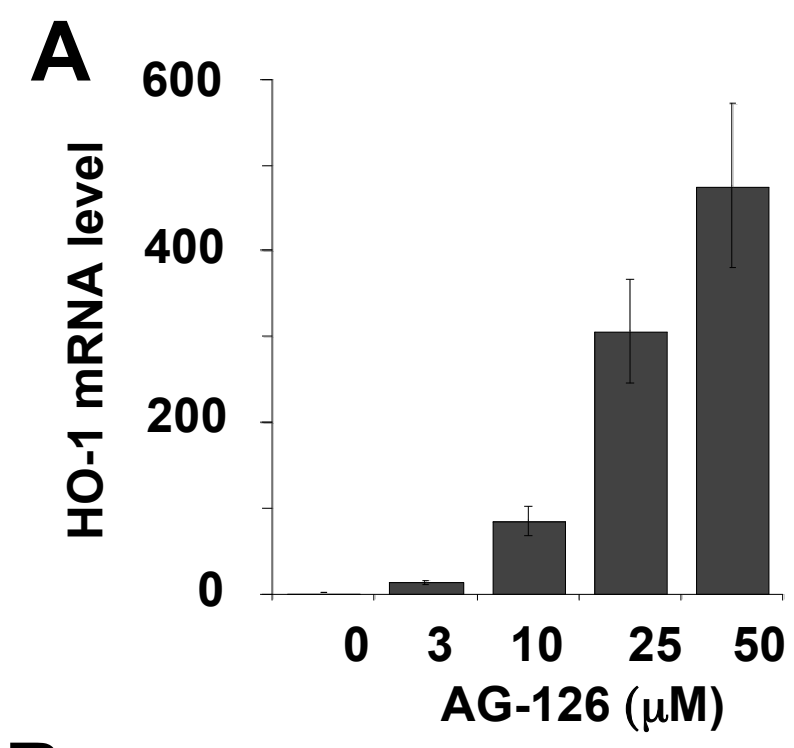

B
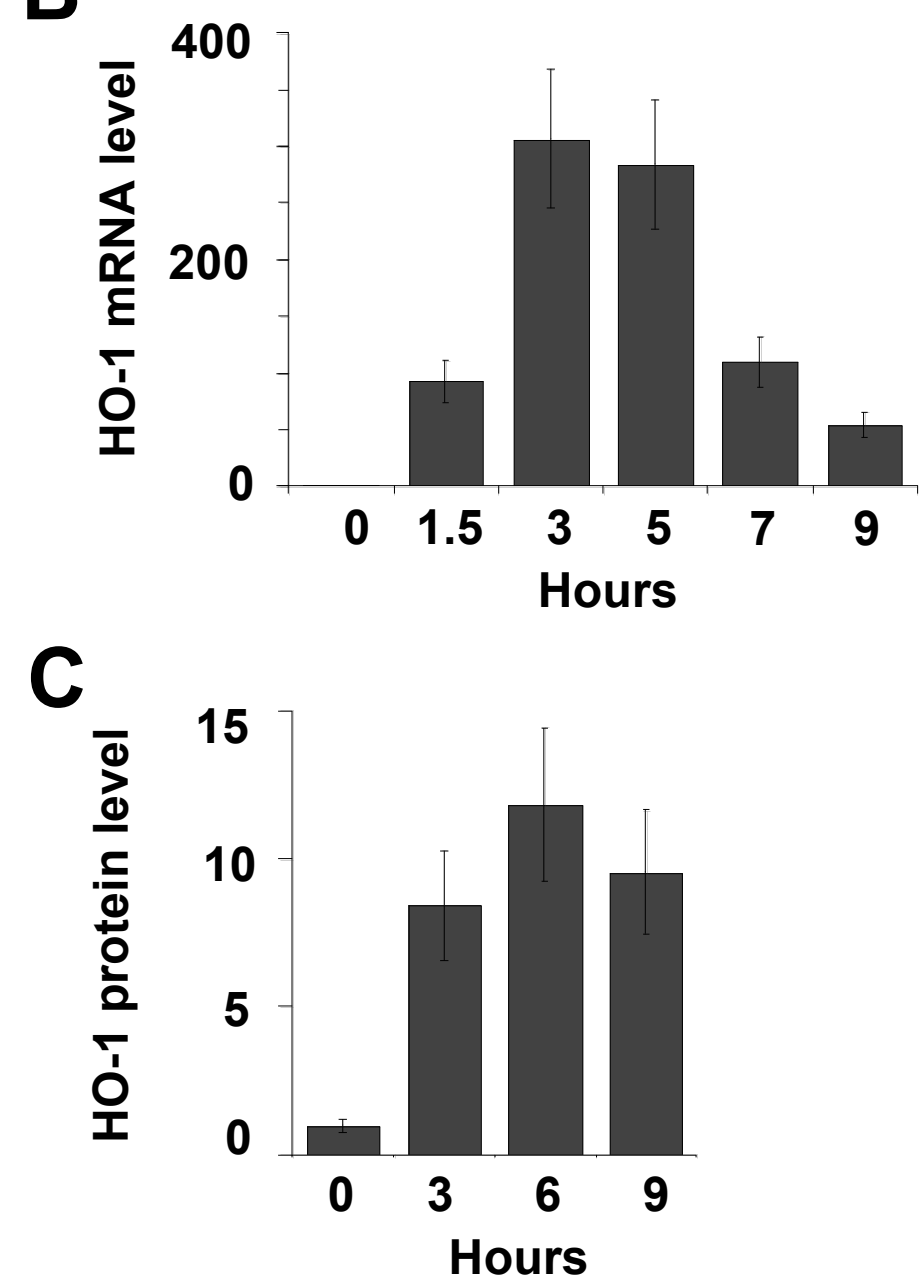
Fig. 2

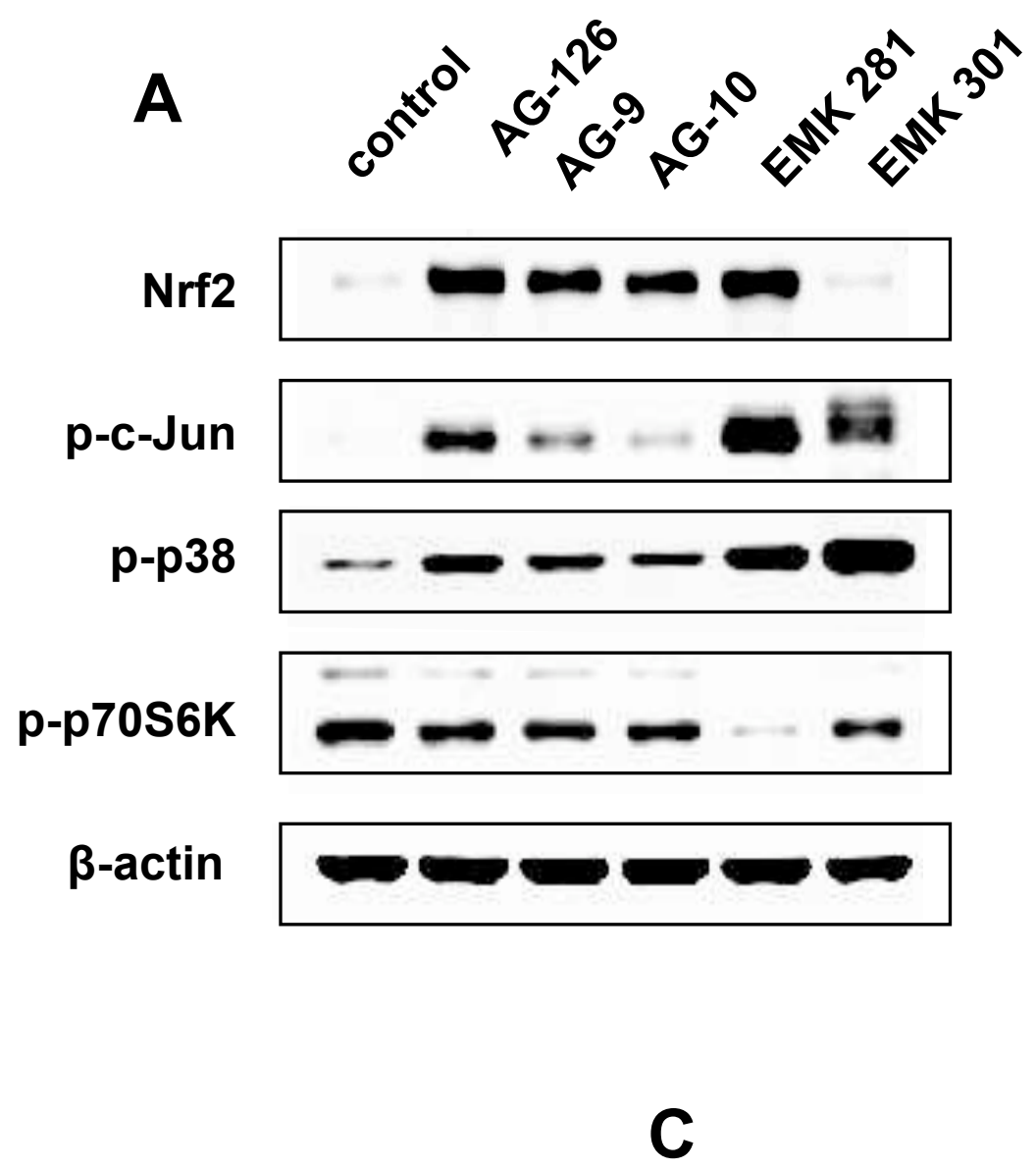

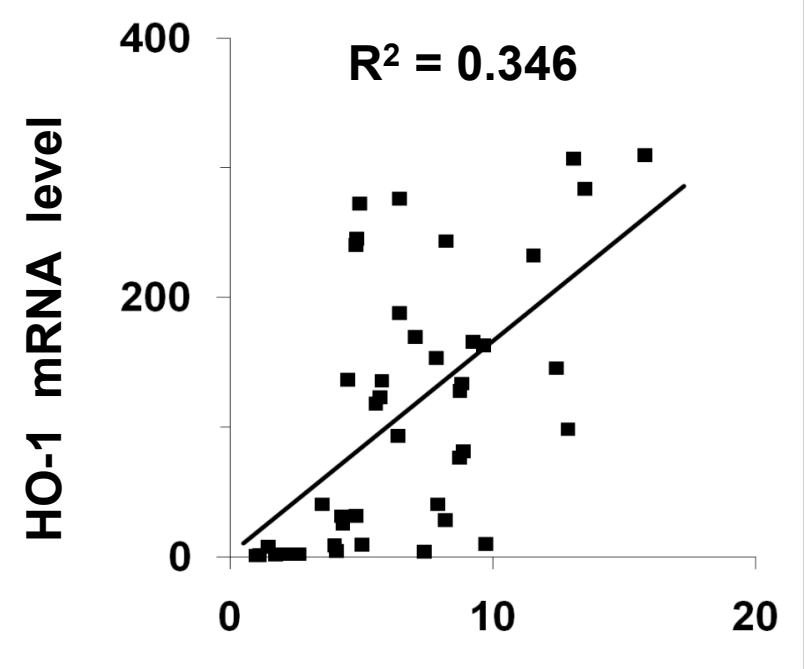

Nrf2 level

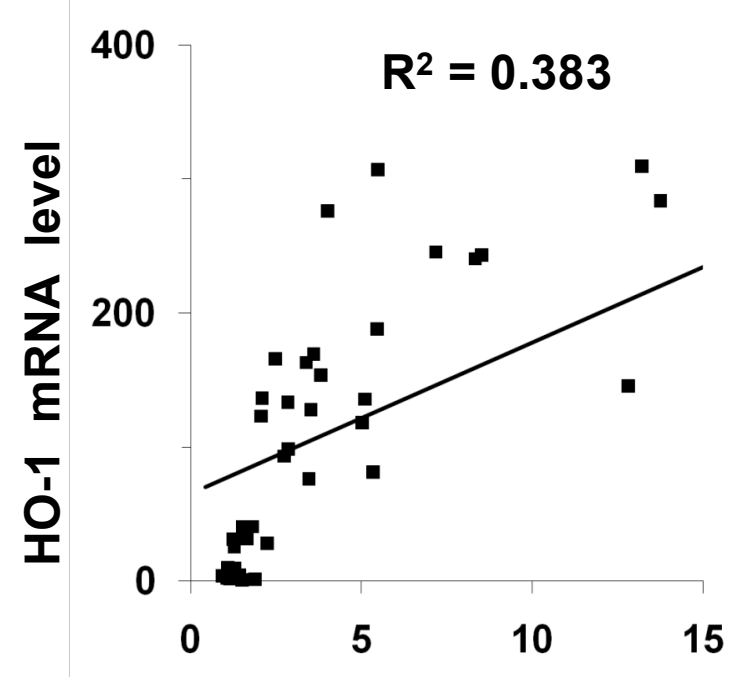

p-cJun level 
Fig. 3

--F-- menadione

$\neg \quad$ AG 126 and menadione

A

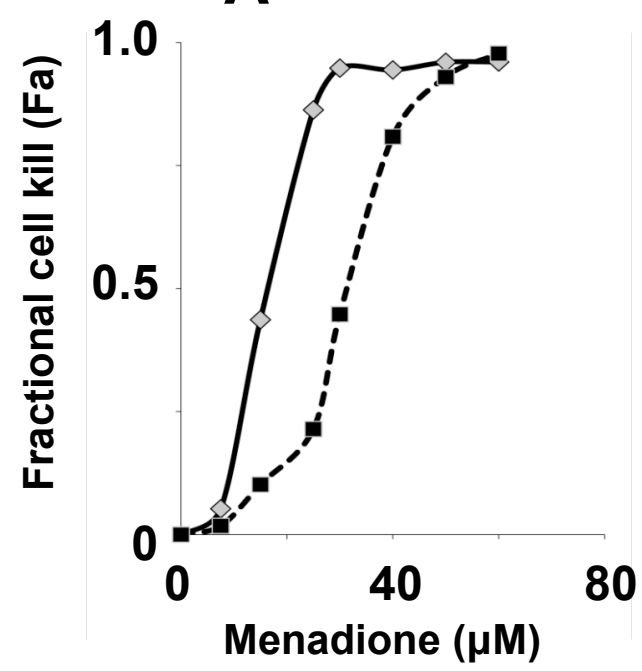

B

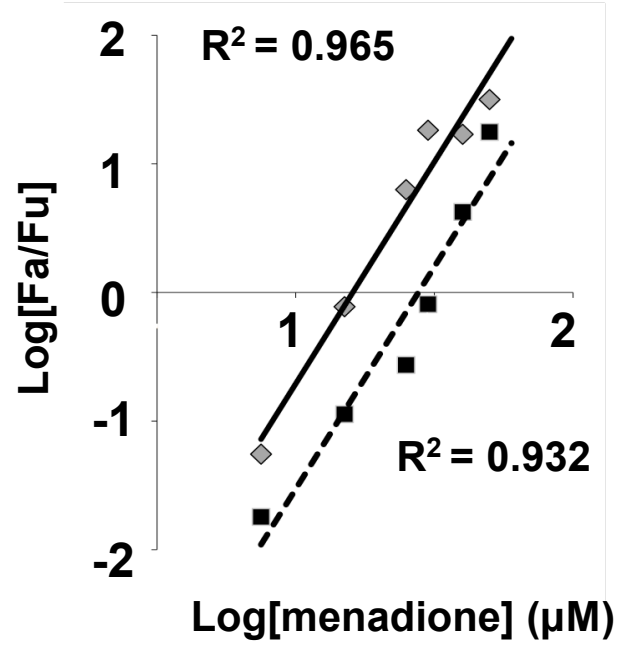

C

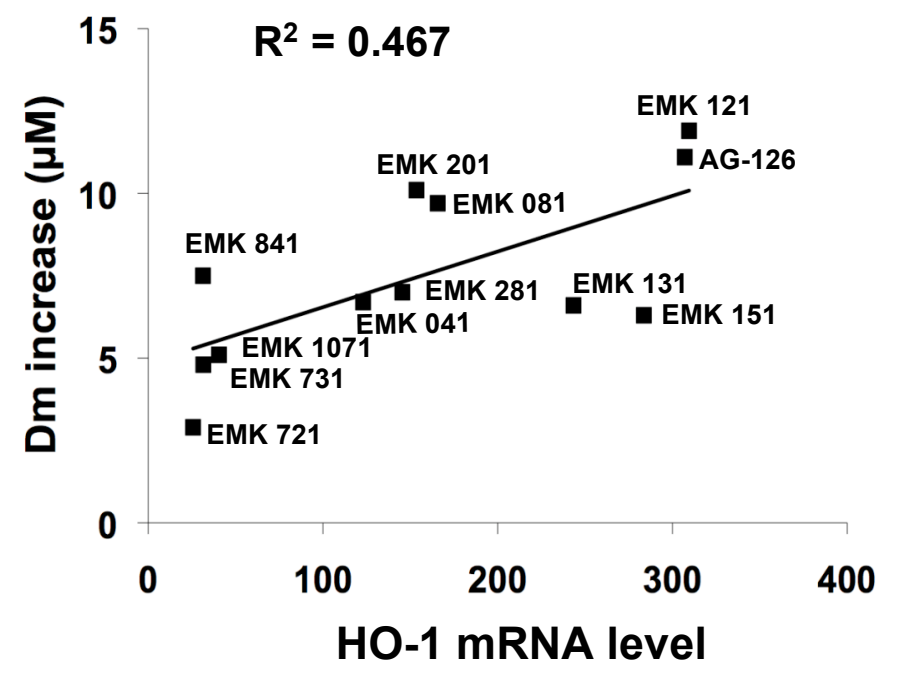

D

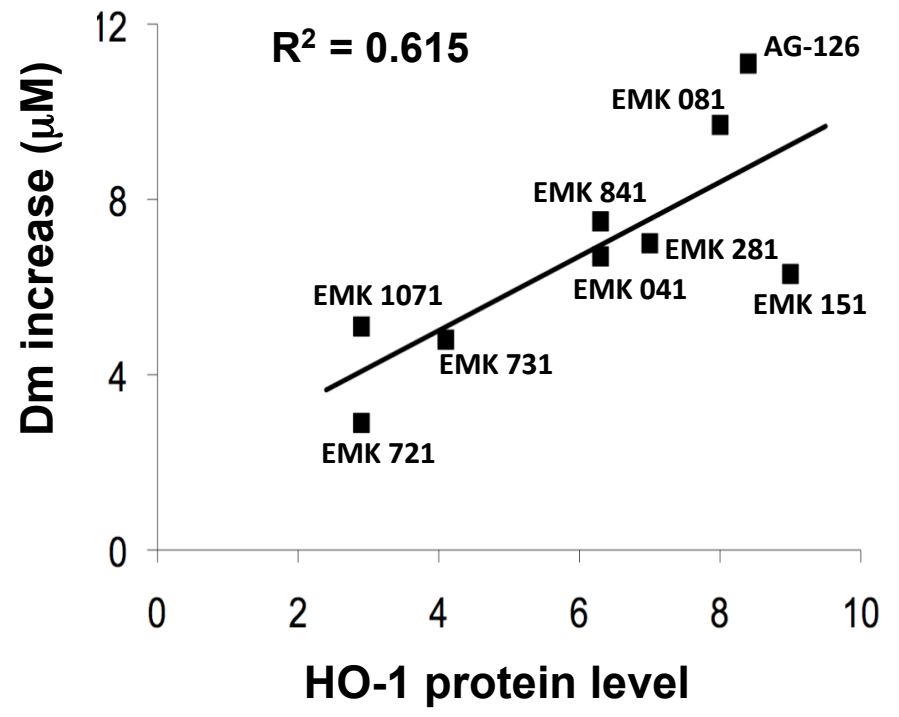


Fig. 4

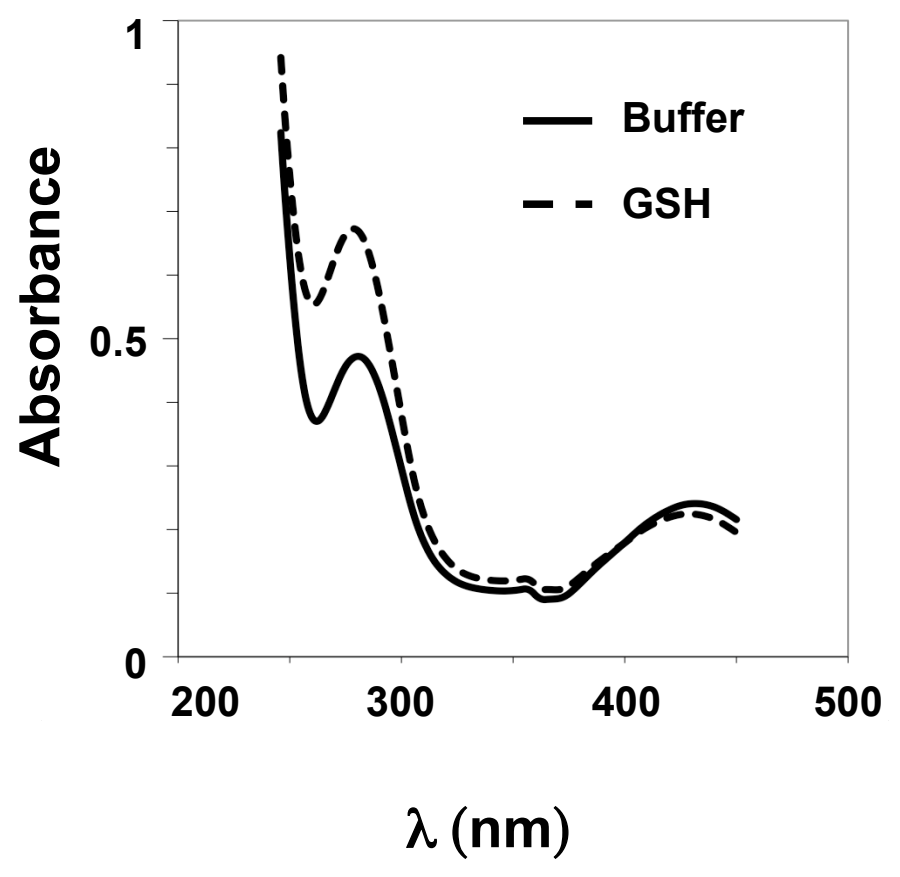


Fig. 5
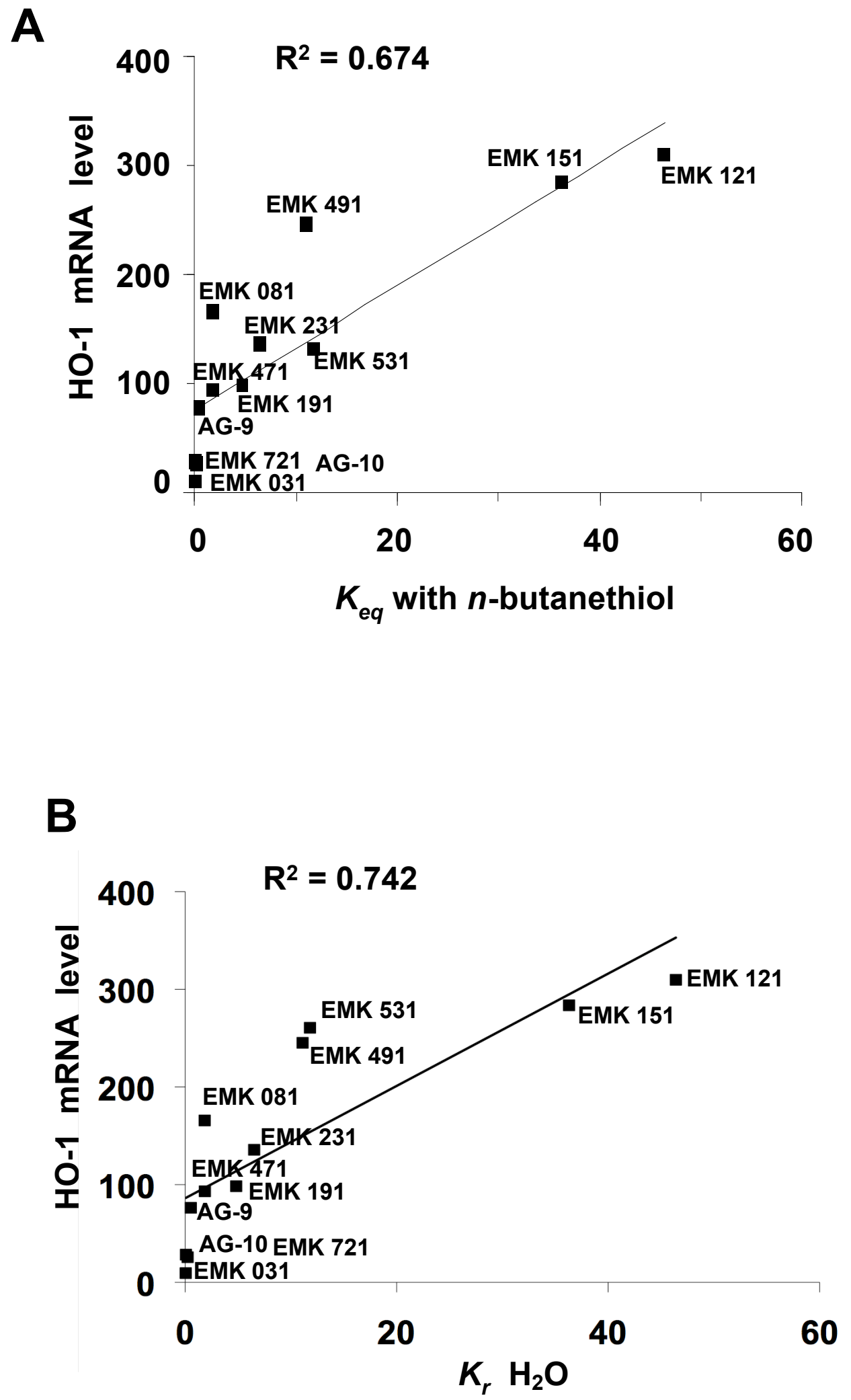
Fig. 6
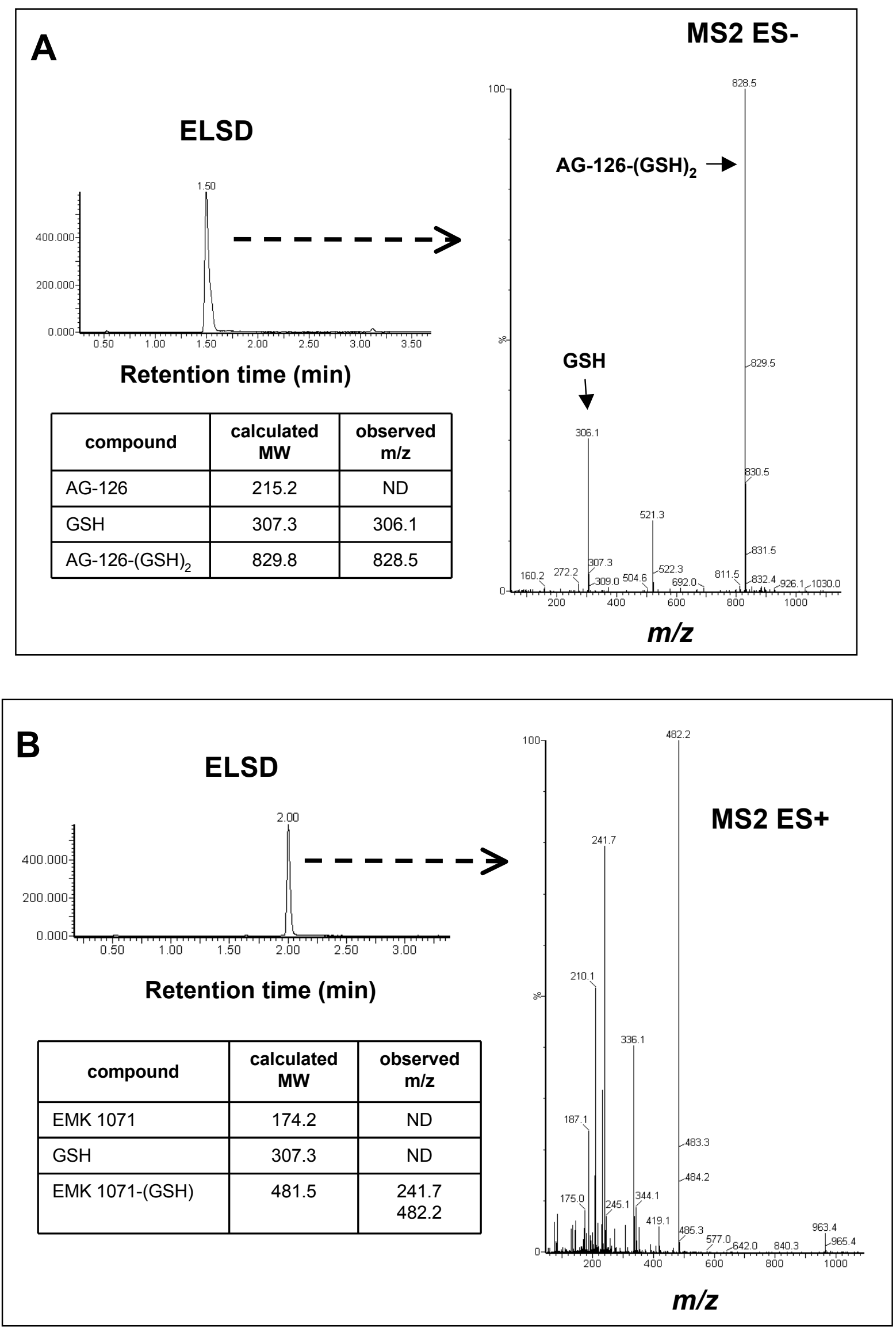
Fig. 6

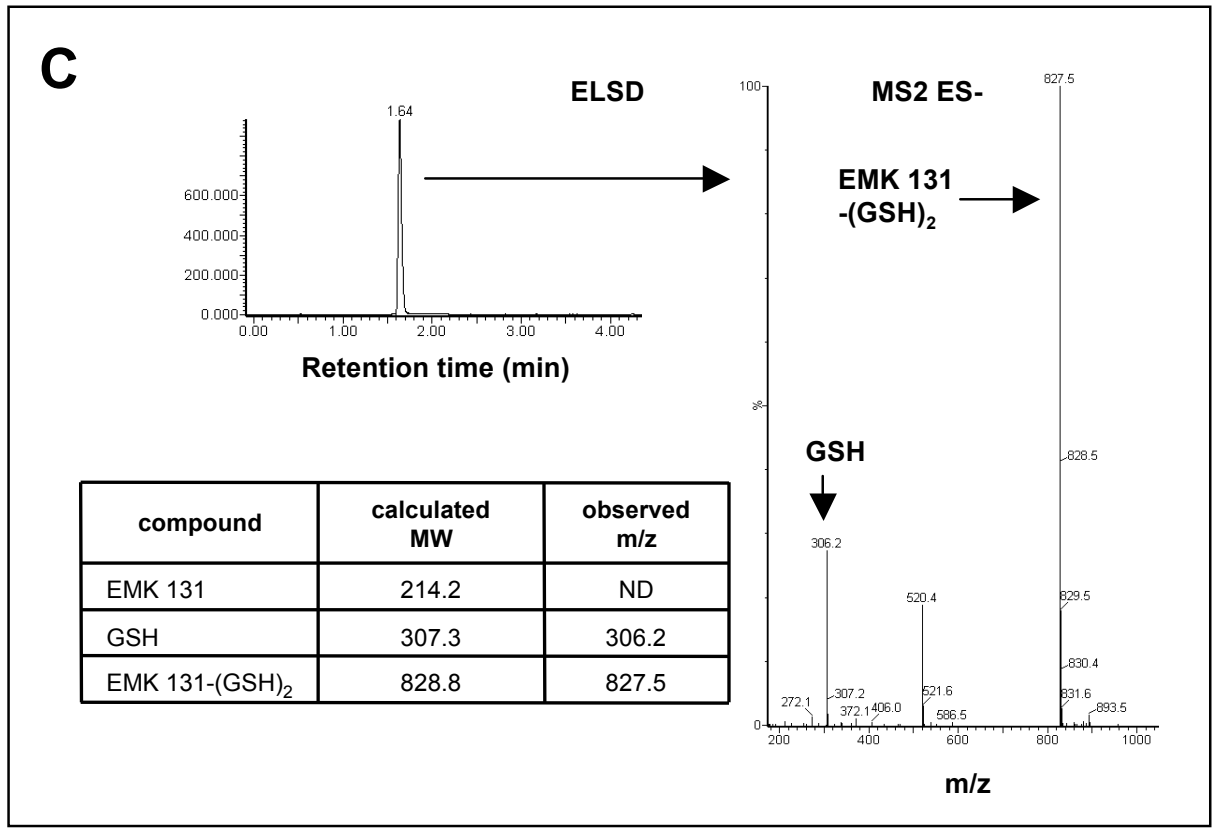

\section{D}

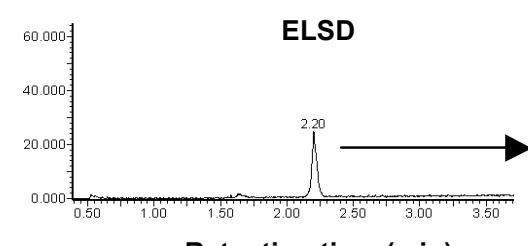

Retention time (min)

\begin{tabular}{|l|c|c|}
\hline \multicolumn{1}{|c|}{ Compound } & $\begin{array}{c}\text { calculated } \\
\text { MW }\end{array}$ & $\begin{array}{c}\text { observed } \\
\mathbf{m} / \mathbf{z}\end{array}$ \\
\hline EMK 721 & 214.2 & ND \\
\hline GSH & 307.3 & ND \\
\hline EMK 721-(GSH) & 521.5 & 261.7 \\
& & 522.2 \\
\hline
\end{tabular}
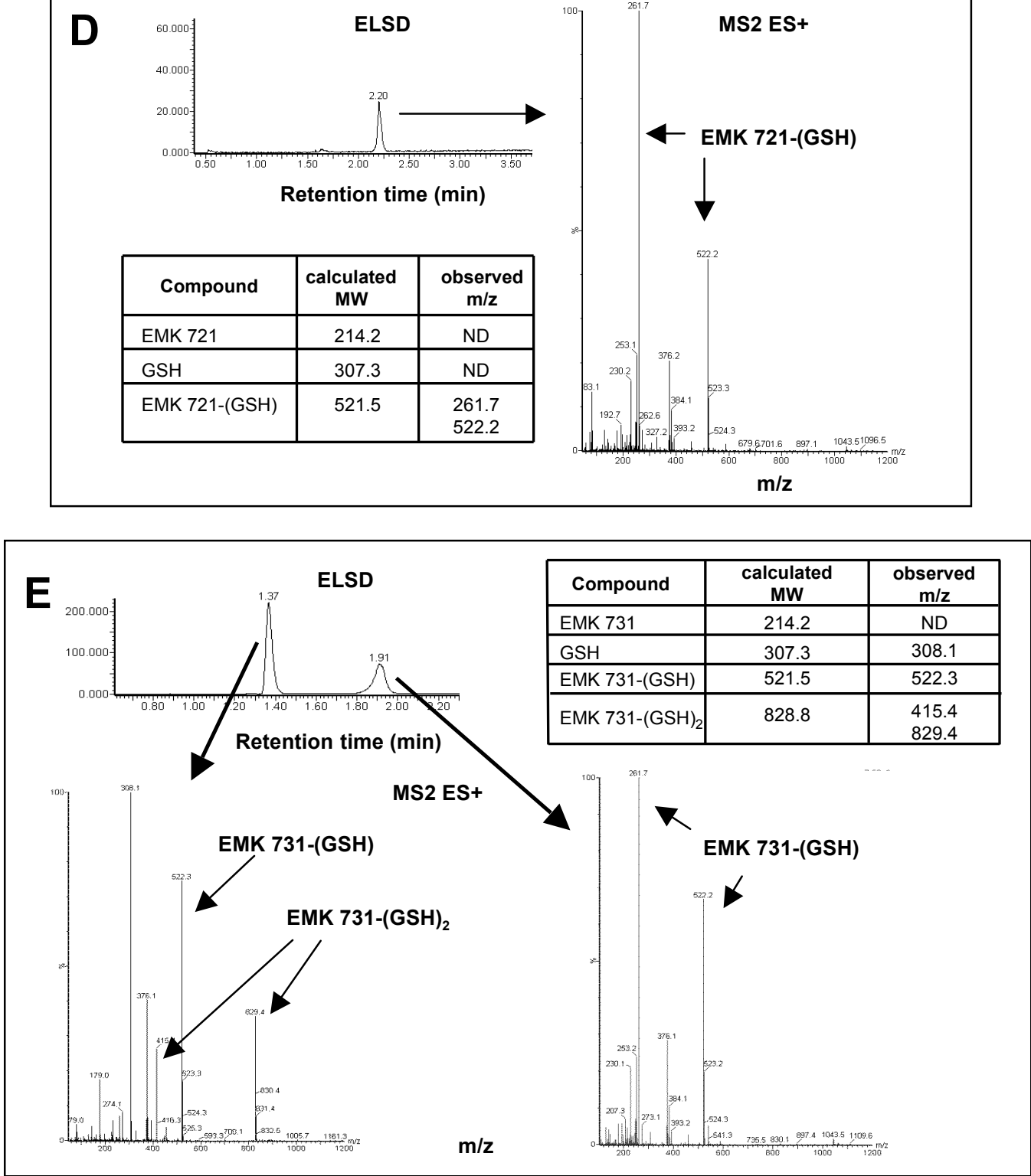
Fig. 7

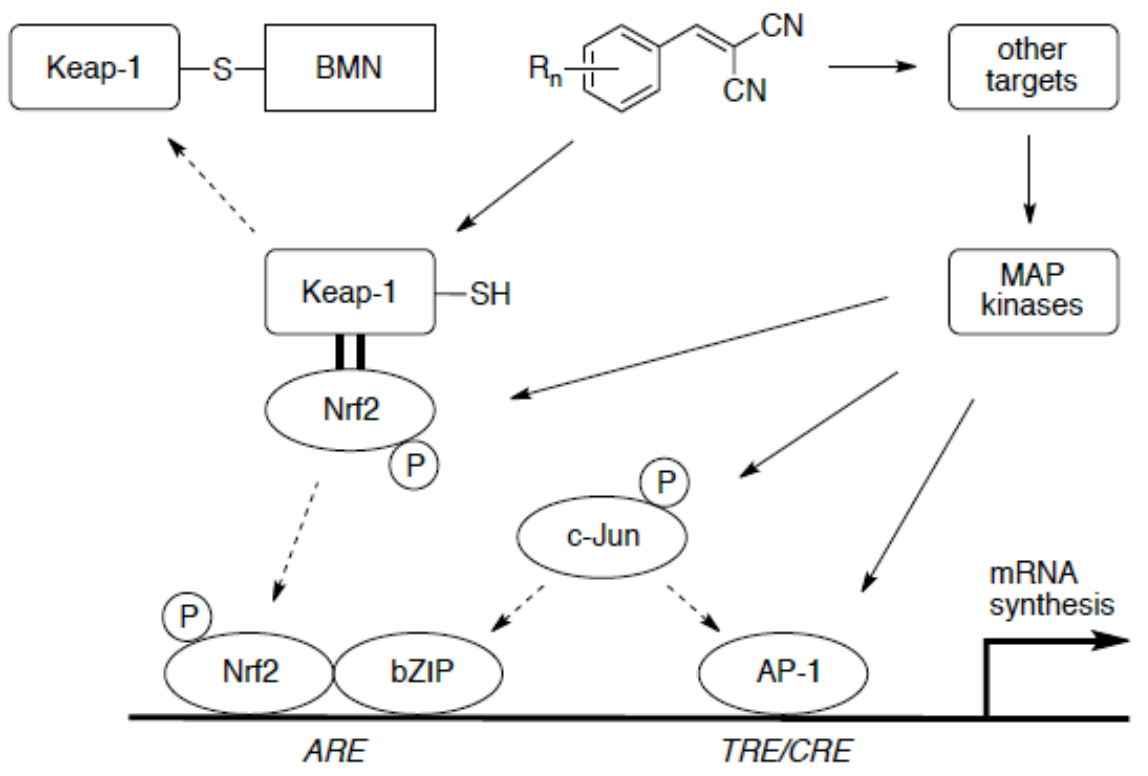




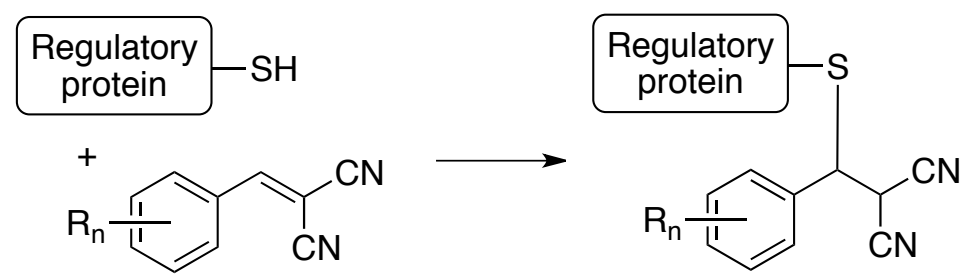

